\title{
Determination of the rate constants for the carbon dioxide to bicarbonate inter-conversion in $\mathrm{pH}$-buffered seawater systems
}

\author{
K.G. Schulz ${ }^{\text {a,* }}$, U. Riebesell ${ }^{\mathrm{a}}$, B. Rost ${ }^{\mathrm{b}}$, S. Thoms ${ }^{\mathrm{b}}$, R.E. Zeebe ${ }^{\mathrm{c}}$ \\ a Leibniz Institute for Marine Sciences, Düsternbrooker Weg 20, 24105 Kiel, Germany \\ b Alfred Wegener Institute for Polar and Marine Research, P.O. Box 12016, 27515 Bremerhaven, Germany \\ ${ }^{c}$ University of Hawaii at Manoa SOEST Department of Oceanography 1000 Pope Road, MSB, 504 Honolulu, HI 96822, USA
}

Received 20 April 2005; received in revised form 11 November 2005; accepted 11 November 2005

Available online 4 January 2006

\begin{abstract}
Experimental setups to study modes of inorganic carbon acquisition and fixation rates by marine phytoplankton commonly make use of so-called disequilibrium techniques. The chemical or isotopic disequilibrium, either caused by phytoplankton cells taking up inorganic carbon or by a small disturbance of the isotopic equilibrium in the carbonate system, requires to account for the relatively slow chemical interconversion of carbon dioxide $\left(\mathrm{CO}_{2}\right)$ to bicarbonate $\left(\mathrm{HCO}_{3}^{-}\right)$in seawater. Because in such experiments a constant $\mathrm{pH}$ is a prerequisite, $\mathrm{pH}$ buffers are generally used. However, a possible influence of such buffers on the kinetics of the carbonate system has hitherto not been investigated. Here, a model of the carbonate system in seawater is employed to show how $\mathrm{pH}$ buffers are operating. Furthermore, a new approach is presented to determine the rate constants, $k_{+}$and $k_{-}$, for the conversion reaction of $\mathrm{CO}_{2}$ to $\mathrm{HCO}_{3}^{-}$and vice versa, by means of membrane inlet mass spectrometry (MIMS). For the two pH buffers tested (HEPES and BICINE) it is shown that measured rate constants are in good agreement with calculated values for $k_{+}$and $k_{-}$in a pH range of 7 to 8.5 and at temperatures from 10 to $25{ }^{\circ} \mathrm{C}$.
\end{abstract}

(c) 2005 Elsevier B.V. All rights reserved.

Keywords: $\mathrm{CO}_{2} \mathrm{HCO}_{3}^{-}$interconversion; Rate constants; $\mathrm{pH}$ buffer; Disequilibrium; MIMS

\section{Introduction}

In the last 200 years, starting with the industrial revolution, the ocean has taken up $\sim 50 \%$ of the carbon dioxide $\left(\mathrm{CO}_{2}\right)$ emitted by mankind's consumption of fossil fuels. The projected doubling of current atmo-

\footnotetext{
* Corresponding author. Tel.: +49 431600 4510; fax: +49 431600 1515.

E-mail addresses: kschulz@ifm-geomar.de (K.G. Schulz), uriebesell@ifm-geomar.de (U. Riebesell),brost@awi-bremerhaven.de (B. Rost), sthoms@awi-bremerhaven.de (S. Thoms), zeebe@hawaii.edu (R.E. Zeebe).
}

spheric $\mathrm{CO}_{2}$ around the year 2100 (Houghton et al., 1995 ) and its continuing oceanic uptake will give rise to a $60 \%$ increase in hydrogen ion concentration in the surface ocean (Sabine et al., 2004). This ocean acidification also involves a redistribution in the dissolved inorganic carbon (DIC) pool, increasing $\mathrm{CO}_{2}$ and bicarbonate $\left(\mathrm{HCO}_{3}^{-}\right)$at the expense of carbonate ion $\left(\mathrm{CO}_{3}^{2-}\right)$ concentrations. It has been shown, both in experimental and in modelling studies, that mechanisms and efficiencies of inorganic carbon acquisition by marine phytoplankton, which is responsible for about half of global net primary production (Field et al., 1998), are sensitive to the availability of $\mathrm{CO}_{2}$ in seawater (Burkhardt et al., 2001; Rost et al., 2003; Thoms 
et al., 2001). Moreover, these can differ greatly between various groups of phytoplankton species (Rost et al., 2003 , in press). The consequences of future DIC redistribution for species composition and inorganic carbon fixation, however, are largely unknown. Assessment of these potential changes includes studies on mechanisms and efficiencies of inorganic carbon acquisition by different phytoplankton groups, making use of socalled disequilibrium techniques. While the mass spectrometric approach measures the disequilibrium caused by photosynthetic uptake of inorganic carbon (Badger et al., 1994), the ${ }^{14} \mathrm{C}$ disequilibrium technique monitors inorganic carbon fixation upon a small disturbance in the isotopic equilibrium of the carbonate system (Cooper et al., 1969; Espie and Colman, 1986). Both methods require exact knowledge of the response of the carbonate system to the disequilibrium employed, i.e., the kinetic rate constants for the chemical interconversion between $\mathrm{CO}_{2}$ and $\mathrm{HCO}_{3}^{-}$. Here we present a method for the exact determination of these rate constants by means of membrane inlet mass spectrometry (MIMS) and compare it with an approach described previously. Furthermore, adopting a model of the carbonate system in seawater, we explore the validity of the assumptions associated with these two approaches.

\section{Methods}

\subsection{The experimental setup}

All measurements were performed in artificial seawater following the recipe of Roy et al. (1993) without addition of DIC. The artificial seawater was divided into two batches to which BICINE or HEPES buffer were added yielding final concentrations of $50 \mu \mathrm{mol} \mathrm{kg} \mathrm{kg}^{-1}$. Sub-samples were taken and their $\mathrm{pH}$ was adjusted at room temperature to values of approximately 7.0, 8.0 and 8.4 by addition of $\mathrm{NaOH}$. Subsamples were then incubated at temperatures of 11,17 and $26{ }^{\circ} \mathrm{C}$. For a measurement $8 \mathrm{ml}$ of a seawater sample was filled into a thermostated cuvette (set to the desired temperature), attached to a sectorfield multicollector mass spectrometer (Isoprime; GV Instruments, England) via a gas permeable membrane $(0.01 \mathrm{~mm}$ PTFE) inlet system. The area for gas exchange via the inlet system was about $24 \mathrm{~mm}^{2}$ and was located at the bottom of the cuvette. The cuvette was closed without headspace to prevent significant gas exchange between atmosphere and water, and was equipped with a magnetic stirring rod to enhance mixing. Manipulations of the carbonate system in the cuvette were carried out via a tiny hole drilled into the stopper. Changes in concentrations of
${ }^{12} \mathrm{CO}_{2}$ and ${ }^{13} \mathrm{CO}_{2}$, the only species of dissolved inorganic carbon (DIC) which are measured directly by the membrane inlet mass spectrometer (MIMS), upon disturbance of the seawater carbonate system were monitored continuously with a resolution of $0.1 \mathrm{~s}$ (carbon species without ${ }^{13} \mathrm{C}$ or ${ }^{12} \mathrm{C}$ notation will refer to the sum of both). The MIMS was calibrated for $\left[\mathrm{CO}_{2}\right]$ by injections of known amounts of $\mathrm{NaH}^{12} \mathrm{CO}_{3}\left(\sim 99 \%{ }^{12} \mathrm{C}\right)$ and $\mathrm{NaH}^{13} \mathrm{CO}_{3}\left(\sim 99 \%{ }^{13} \mathrm{C}\right)$ solutions $\left(10 \mathrm{mmol} \mathrm{kg}{ }^{-1}\right)$ into the cuvette filled with $8 \mathrm{ml}$ of $0.2 \mathrm{M} \mathrm{HCl}$. As in such acidic solution DIC is only present as $\mathrm{CO}_{2}$ the measured $\mathrm{CO}_{2}$ recording can be directly converted into concentration. The $\mathrm{CO}_{2}$ baseline was determined by injection of $20 \mu \mathrm{l}$ of $10 \mathrm{M} \mathrm{NaOH}$. This increased seawater $\mathrm{pH}$ to values at which $\left[\mathrm{CO}_{2}\right]$ is practically zero. As a single measurement did not exceed 10 min $\mathrm{CO}_{2}$ consumption by the mass spectrometer through the membrane inlet system was negligible.

Special care was taken in determining the $\mathrm{pH}$ in all buffered seawater solutions. Known amounts $(40 \mu \mathrm{l})$ of a $\mathrm{NaHCO}_{3}$ solution $\left(100 \mathrm{mmol} \mathrm{kg}{ }^{-1}\right)$ were added to these and subsequent equilibration in the $\mathrm{CO}_{2}$ signal was monitored. The $\left[\mathrm{CO}_{2}\right]$ calibration of the MIMS was used to determine the DIC to $\mathrm{CO}_{2}$ ratio $\left(\mathrm{R}_{\mathrm{C}}\right)$ in equilibrium. Together with the dissociation constants of carbonic acid of Roy et al. (1993), the pH was calculated on the total scale (for details see Zeebe and Wolf-Gladrow (2001)). The $\mathrm{pH}$ of the seawater buffered with HEPES or BICINE remained rather constant $\left( \pm 0.05\right.$ units) upon $\mathrm{NaHCO}_{3}$ addition which was checked independently with a $\mathrm{pH}$ meter.

Previously, similar experimental setups were used for estimation of the rate constants for the $\mathrm{CO}_{2}$ to $\mathrm{HCO}_{3}^{-}$interconversion (e.g., Badger et al., 1994; Sültemeyer et al., 1995). Basically, $\mathrm{CO}_{2}$ evolution was measured after injection of known amounts of a $\mathrm{K}_{2} \mathrm{CO}_{3}$ solution (100 mmol kg-1) into DIC free seawater medium. In the alkaline $\mathrm{K}_{2} \mathrm{CO}_{3}$ solution $(\mathrm{pH} \sim 11)$ DIC is only present as $\mathrm{CO}_{3}^{2-}$ and $\mathrm{HCO}_{3}^{-}$while $\mathrm{CO}_{2}$ is practically zero. Hence, injection of such solution will result in a net conversion of $\mathrm{CO}_{3}^{2-}$ to $\mathrm{HCO}_{3}^{-}$and finally to $\mathrm{CO}_{2}$ in any seawater sample buffered at a $\mathrm{pH}$ lower than that of the $\mathrm{K}_{2} \mathrm{CO}_{3}$ solution. From the initial slope of the $\mathrm{CO}_{2}$ evolution signal, monitored with the MIMS, the rate constants were then estimated. However, three assumptions regarding this procedure remain to be tested. First, the $\mathrm{pH}$ buffer is able to keep the $\mathrm{pH}$ constant on time scales of seconds recorded by the MIMS. Second, on these time scales the $\mathrm{CO}_{3}^{2-}$ and $\mathrm{HCO}_{3}^{-}$pools are always in chemical equilibrium. And third, the initial reaction is dominated by the $\mathrm{HCO}_{3}^{-}$to $\mathrm{CO}_{2}$ conversion, so that the back-reaction can safely be 
ignored. The first two assumptions are discussed in Sections 3.1, 3.2 and 3.4. As the third clearly poses a limitation a new method was developed which uses not only the initial slope but rather the entire $\mathrm{CO}_{2}$ evolution curve, allowing explicitly for the back-reaction to take place. Practically, this is achieved by nonlinearly fitting a suitable equation to the measured $\mathrm{CO}_{2}$ evolution curve leading to determination of the rate constants. However, these can also be assessed by adding known amounts of a solution in which DIC is mainly present in the form of $\mathrm{CO}_{2}$. Such a solution was prepared by bubbling the artificial seawater described above with $\mathrm{CO}_{2}$ at the desired temperature. Injection of this solution with a $\mathrm{pH} \sim 3.8$ in any seawater sample, buffered at a $\mathrm{pH}$ higher than that, will result in a net conversion of $\mathrm{CO}_{2}$ to $\mathrm{HCO}_{3}^{-}$. Therefore, the MIMS will monitor a decrease in the $\mathrm{CO}_{2}$ signal, the opposite reaction compared to $\mathrm{K}_{2} \mathrm{CO}_{3}$ addition.

\subsection{The chemical background and the development of} the fitting equations for addition of $\mathrm{K}_{2} \mathrm{CO}_{3}$ and $\mathrm{CO}_{2}$ solutions

Inorganic carbon in aqueous solutions is predominantly present in three forms, $\mathrm{CO}_{2}(\mathrm{aq}), \mathrm{HCO}_{3}^{-}$and $\mathrm{CO}_{3}^{2-}$. The fourth compound, true carbonic acid $\left(\mathrm{H}_{2} \mathrm{CO}_{3}\right)$, constitutes less than $0.1 \%$ of the total dissolved inorganic carbon (DIC) and is therefore generally added to the $\mathrm{CO}_{2}$ (aq) pool, defining $\mathrm{CO}_{2}$ as the sum of $\mathrm{CO}_{2}$ (aq) and $\mathrm{H}_{2} \mathrm{CO}_{3}$. Then, this system is characterized by two reactions. The first can be described as the relation between the $\mathrm{CO}_{2}$ and $\mathrm{HCO}_{3}^{-}$ pools in equilibrium

$K_{1}^{*}=\frac{\left[\mathrm{H}^{+}\right]\left[\mathrm{HCO}_{3}^{-}\right]}{\left[\mathrm{CO}_{2}\right]}=\frac{k_{+}}{k_{-}}$

with $K_{1}^{*}$ being the stoichiometric equilibrium constant and $k_{+}$and $k_{-}$referring to the rate constants for the overall reaction of $\mathrm{CO}_{2}$ to $\mathrm{HCO}_{3}^{-}$and vice versa, respectively. The kinetics between these pools can then be described as

$\mathrm{H}_{2} \mathrm{O}+\mathrm{CO}_{2} \underset{k_{-}}{\stackrel{k_{+}}{\rightleftharpoons}} \mathrm{HCO}_{3}^{-}+\mathrm{H}^{+}$

This overall reaction comprises several reaction pathways for the $\mathrm{CO}_{2}$ to $\mathrm{HCO}_{3}^{-}$interconversion, given by Eqs. (17) and (18). Please note that in Eq. (17) the reaction pathway via $\mathrm{H}_{2} \mathrm{CO}_{3}$ is implicity included (see Appendix). Rate constants are dependent on temperature and salinity, but the actual rate at which equilibrium will be restored after a disturbance in one pool also depends on $\mathrm{pH}$ (note the $\left[\mathrm{H}^{+}\right]$in Eq. (1)). The second reaction in the carbonate system, the one between $\mathrm{HCO}_{3}^{-}$and $\mathrm{CO}_{3}^{2-}$, is virtually instantaneous compared to the reaction in Eq. (2), as it involves just protonation and deprotonation steps (see Section 3.4 for details).

The ratio of [DIC] to $\mathrm{CO}_{2}$ in equilibrium $\left(\left[\mathrm{CO}_{2}\right]_{\mathrm{eq}}\right)$ as measured with the MIMS is defined as

$\mathrm{R}_{\mathrm{C}}=\frac{[\mathrm{DIC}]}{\left[\mathrm{CO}_{2}\right]_{\mathrm{eq}}}$.

From Eq. (2) follows that changes in $\left[\mathrm{CO}_{2}\right]$ can be described as:

$\frac{\mathrm{d}\left[\mathrm{CO}_{2}\right]}{\mathrm{d} t}=+k_{-}\left[\mathrm{H}^{+}\right]\left[\mathrm{HCO}_{3}^{-}\right]-k_{+}\left[\mathrm{CO}_{2}\right]$

this is a safe assumption on a time scale of seconds, as the $\mathrm{HCO}_{3}^{-}$and $\mathrm{CO}_{3}^{2-}$ pools will be in equilibrium by the comparatively rapid reactions between them (see Section 3.4 for details). As $\left[\mathrm{CO}_{2}\right]$ is the only parameter which can be monitored online by the MIMS, ([DIC]$\left.\left[\mathrm{CO}_{2}\right]-\left[\mathrm{CO}_{3}^{2-}\right]\right)$ is substituted for $\left[\mathrm{HCO}_{3}^{-}\right]$. Now, the only unknown in a redistribution of the carbonate species is $\left[\mathrm{CO}_{3}^{2-}\right]$. Note that $[\mathrm{DIC}]$ is always conserved, even when the relative contribution of the three carbonate species changes. If the $\mathrm{pH}$ buffer (HEPES, or BICINE) is able to keep the $\mathrm{pH}$ constant (this assumption will be investigated with a model described in Section 2.4), $\left[\mathrm{CO}_{3}^{2-}\right]$ can be described as a constant fraction $\mathrm{f}$ of $\left[\mathrm{HCO}_{3}^{-}\right]$, yielding $\left[\mathrm{CO}_{3}^{2-}\right]=\mathrm{f}\left[\mathrm{HCO}_{3}^{-}\right]$(see 3.4 for details). Combining the last two equations gives

$\left[\mathrm{HCO}_{3}^{-}\right]=\frac{[\mathrm{DIC}]-\left[\mathrm{CO}_{2}\right]}{(1+\mathrm{f})}$.

By substituting $\left[\mathrm{HCO}_{3}^{-}\right]$from Eq. (5) into Eq. (4) it follows that

$\frac{\mathrm{d}\left[\mathrm{CO}_{2}\right]}{\mathrm{d} t}=+k_{-}\left[\mathrm{H}^{+}\right] \frac{[\mathrm{DIC}]-\left[\mathrm{CO}_{2}\right]}{(1+\mathrm{f})}-k_{+}\left[\mathrm{CO}_{2}\right]$.

Rearrangement with $\alpha=1 /(1+f)$ yields

$\frac{\mathrm{d}\left[\mathrm{CO}_{2}\right]}{\mathrm{d} t}=-\left(\alpha k_{-}\left[\mathrm{H}^{+}\right]+k_{+}\right)\left[\mathrm{CO}_{2}\right]+\alpha k_{-}\left[\mathrm{H}^{+}\right][\mathrm{DIC}]$.

From here on, the paths for describing the $\mathrm{CO}_{2}$ evolution curve upon addition of a $\mathrm{K}_{2} \mathrm{CO}_{3}$ or $\mathrm{CO}_{2}$ solution split up. First, $\mathrm{K}_{2} \mathrm{CO}_{3}$ addition is considered. As right after the injection of a $\mathrm{K}_{2} \mathrm{CO}_{3}$ solution the reaction involving $k_{-}$will be the dominant one, $k_{+}$is expressed in terms of $k_{-}$as described by equilibrium conditions in Eq. (1). Additionally, for convenience, the rate constant $k_{-}$is combined with $\left[\mathrm{H}^{+}\right]$giving $k_{-}^{*}=k_{-}\left[\mathrm{H}^{+}\right]$(note 
that this is justified by the assumption that the $\mathrm{pH}$ is constant).

$$
\begin{aligned}
\frac{k_{+}}{k_{-}^{*}} & =\frac{\left[\mathrm{HCO}_{3}^{-}\right]_{\mathrm{eq}}}{\left[\mathrm{CO}_{2}\right]_{\mathrm{eq}}}=\frac{\alpha\left([\mathrm{DIC}]-\left[\mathrm{CO}_{2}\right]_{\mathrm{eq}}\right)}{\left[\mathrm{CO}_{2}\right]_{\mathrm{eq}}} \\
& =\alpha\left(\mathrm{R}_{\mathrm{C}}-1\right)
\end{aligned}
$$

Substituting now $k_{+}$in Eq. (7) it follows that

$$
\frac{\mathrm{d}\left[\mathrm{CO}_{2}\right]}{\mathrm{d} t}=-\alpha \mathrm{R}_{\mathrm{C}} k_{-}^{*}\left[\mathrm{CO}_{2}\right]+\alpha k_{-}^{*}[\mathrm{DIC}] \text {. }
$$

The general solution of the homogeneous version of Eq. (9) (i.e., $[\mathrm{DIC}]=0$ ) is

$$
\left[\mathrm{CO}_{2}\right](t)=A \exp \left(-\alpha \mathrm{R}_{C} k_{-}^{*} t\right)
$$

where $A$ is a constant to be determined from the initial conditions. One arbitrary solution of the non-homogeneous equation is (this can usually be found by assuming $\left[\mathrm{CO}_{2}\right](t)=$ constant):

$$
\left[\mathrm{CO}_{2}\right](t)=\frac{1}{\mathrm{R}_{\mathrm{C}}}[\mathrm{DIC}] \text {. }
$$

Hence, the general solution of the non-homogeneous equation is:

$\left[\mathrm{CO}_{2}\right](t)=A \exp \left(-\alpha \mathrm{R}_{\mathrm{C}} k_{-}^{*} t\right)+\frac{1}{\mathrm{R}_{\mathrm{C}}}[\mathrm{DIC}]$

Now $A$ has to be determined from the initial condition $\left[\mathrm{CO}_{2}\right](t=0)=\left[\mathrm{CO}_{2}\right]_{0}=A+\alpha[\mathrm{DIC}] / \alpha \mathrm{R}_{\mathrm{C}}$. And thus

$A=\left[\mathrm{CO}_{2}\right]_{0}-\frac{1}{\mathrm{R}_{\mathrm{C}}}[\mathrm{DIC}]$

which leads to

$$
\begin{aligned}
{\left[\mathrm{CO}_{2}\right](t)=} & \left\{\left[\mathrm{CO}_{2}\right]_{0}-\frac{1}{\mathrm{R}_{\mathrm{C}}}[\mathrm{DIC}]\right\} \exp \left(-\alpha \mathrm{R}_{\mathrm{C}} k_{-}^{*} t\right) \\
& +\frac{1}{\mathrm{R}_{\mathrm{C}}}[\mathrm{DIC}]
\end{aligned}
$$

with $\left[\mathrm{CO}_{2}\right]_{0}$ being the initial $\left[\mathrm{CO}_{2}\right]$ prior to addition of a $\mathrm{K}_{2} \mathrm{CO}_{3}$ solution. The constant $\mathrm{R}_{\mathrm{C}}$ is determined with the MIMS as described above, and $\mathrm{f}$ can be calculated using the second dissociation constants of carbonic acid given by Roy et al. (1993). Then, Eq. (14) is fitted for $k_{-}^{*}$ in a least square procedure to the observed $\mathrm{CO}_{2}$ evolution data upon $\mathrm{K}_{2} \mathrm{CO}_{3}$ addition. From equilibrium conditions described in Eq. (1), $k_{+}$can then be calculated as

$k_{+}=\frac{K_{1}^{*} k_{-}^{*}}{\left[\mathrm{H}^{+}\right]}$

with $k_{-}=k_{-}^{*} /\left[\mathrm{H}^{+}\right]$.
In principle, Eq. (14) is equally suitable for $\mathrm{CO}_{2}$ addition. However, the first dominant reaction will be the conversion of $\mathrm{CO}_{2}$ to $\mathrm{HCO}_{3}^{-}$. Hence, $k_{+}$is substituted for $k_{-}$in Eq. (7). Further rearrangement and solving of the resulting differential equation gives

$$
\begin{aligned}
{\left[\mathrm{CO}_{2}\right](t)=} & \left\{\left[\mathrm{CO}_{2}\right]_{0}-\frac{1}{\mathrm{R}_{\mathrm{C}}}[\mathrm{DIC}]\right\} \exp \left(-\gamma k_{+} t\right) \\
& +\frac{1}{\mathrm{R}_{\mathrm{C}}}[\mathrm{DIC}]
\end{aligned}
$$

with $\gamma=\mathrm{R}_{\mathrm{C}} /\left(\mathrm{R}_{\mathrm{C}}-1\right)$.

\subsection{The fitting procedure}

Fitting of Eqs. (14) and (16) to the observed $\mathrm{CO}_{2}$ evolution curve $\left({ }^{12} \mathrm{CO}_{2}+{ }^{13} \mathrm{CO}_{2}\right)$ upon addition of a $\mathrm{K}_{2} \mathrm{CO}_{3}$ or $\mathrm{CO}_{2}$ solution is achieved by a least square minimization using the Levenberg-Marquardt method (Moré, 1977), yielding $k_{-}$or $k_{+}$, respectively. There are, however, always two processes influencing the $\mathrm{CO}_{2}$ evolution curve in the first couple of seconds following a disturbance in the carbonate system, i.e., changes in the gas flow through the membrane and mixing of the DIC addition in the cuvette. This is accounted for by discarding the first couple of seconds and starting the fitting procedure from the inflection point (see Fig. 1).

As stated earlier, a crucial prerequisite for the fitting equations is that the $\mathrm{pH}$ of the seawater is kept constant by the $\mathrm{pH}$ buffer throughout the measurement. Therefore, in the next section a model of the carbonate system in seawater is described to test this assumption.

\subsection{The model of the carbonate system in seawater}

A model similar to that of Zeebe and Wolf-Gladrow (2001) was developed, including all important reactions of the carbonate system in seawater. Additionally, a parameterization for the kinetics of different $\mathrm{pH}$-buffers was added. Boron species, important constituents in natural seawater, are excluded because they are not contained in the artificial seawater used. The following reactions are considered (the letter A denotes a proton acceptor, i.e., a $\mathrm{pH}$ buffer).

$$
\begin{aligned}
& \mathrm{CO}_{2}+\mathrm{H}_{2} \mathrm{O} \underset{k_{-1}}{\stackrel{k_{+1}}{\rightleftharpoons}} \mathrm{HCO}_{3}^{-}+\mathrm{H}^{+} \\
& \mathrm{CO}_{2}+\mathrm{OH}^{-} \underset{k_{-4}}{\stackrel{k_{+4}}{\rightleftharpoons}} \mathrm{HCO}_{3}^{-}
\end{aligned}
$$




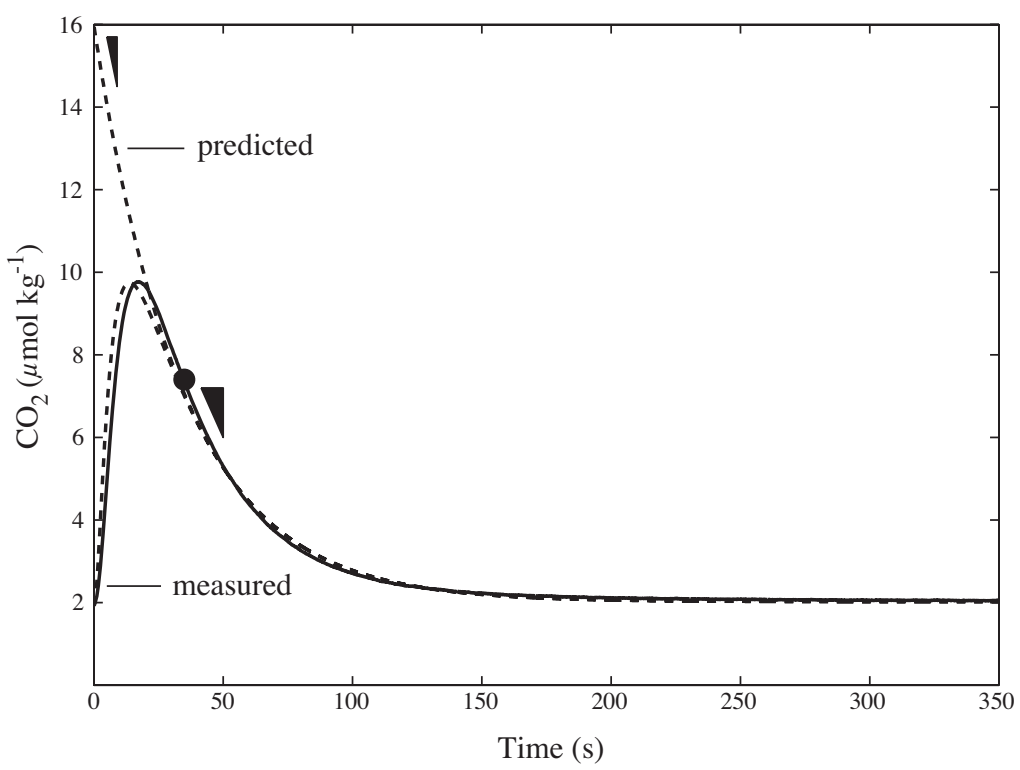

Fig. 1. Example for the measurement of the $\mathrm{CO}_{2}\left({ }^{12} \mathrm{CO}_{2}+{ }^{13} \mathrm{CO}_{2}\right)$ evolution curve as monitored with the MIMS upon an addition of $\sim 14 \mu \mathrm{mol} k \mathrm{~kg}^{-1}$ $\mathrm{CO}_{2}$, and the curve fitting procedure. The solid line depicts the change in $\left[\mathrm{CO}_{2}\right]$ as measured by the MIMS and the dashed line the $\mathrm{CO}_{2}$ evolution curve as predicted by Eq. (16) after the fitting procedure described in Section 2.3. The dot marks the inflection point at which the fitting to the solid line is started. The dashed line increasing constantly prior to that point is the theoretical decline in $\left[\mathrm{CO}_{2}\right](\mathrm{Eq}$. (16)) which would be observed in an ideal situation, i.e. right at time zero, the injected $\mathrm{CO}_{2}$ is mixed homogeneously in the cuvette and detected instantly by the MIMS. To illustrate these processes the theoretical $\mathrm{CO}_{2}$ evolution curve has been modified by multiplication with two exponential terms representing mixing and changing gas flow through the membrane (dashed line starting at the initial $\left[\mathrm{CO}_{2}\right]$ at time zero). This theoretical $\mathrm{CO}_{2}$ evolution curve resembles the measured very well and demonstrates that the fitting procedure after the inflection point is not biased by mixing and changing gas flow through the membrane. The two solid triangles next to the $\mathrm{CO}_{2}$ evolution curves illustrate the respective slopes at time zero and after the inflection point, at which the back-reaction from $\mathrm{HCO}_{3}^{-}$to $\mathrm{CO}_{2}$ is much higher and $\left[\mathrm{CO}_{2}\right]$ is much lower, resulting in a shallower slope. In the case shown, the temperature was $17^{\circ} \mathrm{C}$, the seawater $\mathrm{pH}$ was $\sim 8$ and the $\mathrm{pH}$ buffer used was HEPES.

$\mathrm{CO}_{3}^{2-}+\mathrm{H}^{+} \underset{k_{-5}^{+}}{\stackrel{\mathrm{H}_{+5}^{+}}{\rightleftharpoons}} \mathrm{HCO}_{3}^{-}$

$\mathrm{HCO}_{3}^{-}+\mathrm{OH}^{-} \underset{k_{-5}^{\mathrm{O}^{-}}}{\stackrel{\mathrm{OH}_{+5}^{-}}{\rightleftharpoons}} \mathrm{CO}_{3}^{2-}+\mathrm{H}_{2} \mathrm{O}$

$\mathrm{H}_{2} \mathrm{O} \underset{k_{-6}}{\stackrel{k_{+6}}{\rightleftharpoons}} \mathrm{H}^{+}+\mathrm{OH}^{-}$

$\mathrm{AH} \underset{k_{-a}}{\stackrel{k_{+a}}{\rightleftharpoons}} \mathrm{A}^{-}+\mathrm{H}^{+}$

It is noted that, what is referred to as $k_{+}$or $k_{-}$in Eq. (2) must not be confused with $k_{+1}$ or $k_{-1}$ in Eq. (17). The former are the rate constants for the overall reactions between the $\mathrm{CO}_{2}$ and $\mathrm{HCO}_{3}^{-}$pools in this coupled chemical system. The values for the different reaction rate constants are given in Table 1 . The set of differential equations therefore reads

$$
\begin{aligned}
\frac{\mathrm{d}\left[\mathrm{CO}_{2}\right]}{\mathrm{d} t}= & +\left(k_{-1}\left[\mathrm{H}^{+}\right]+k_{-4}\right)\left[\mathrm{HCO}_{3}^{-}\right] \\
& -\left(k_{+1}+k_{+4}\left[\mathrm{OH}^{-}\right]\right)\left[\mathrm{CO}_{2}\right]
\end{aligned}
$$

$$
\begin{aligned}
\frac{\mathrm{d}\left[\mathrm{HCO}_{3}^{-}\right]}{\mathrm{d} t}= & +\left(k_{+1}+k_{+4}\left[\mathrm{OH}^{-}\right]\right)\left[\mathrm{CO}_{2}\right] \\
& -\left(k_{-1}\left[\mathrm{H}^{+}\right]+k_{-4}\right)\left[\mathrm{HCO}_{3}^{-}\right] \\
& +\left(k_{+5}^{\mathrm{H}^{+}}\left[\mathrm{H}^{+}\right]+k_{+5}^{\mathrm{OH}^{-}}\right)\left[\mathrm{CO}_{3}^{2-}\right] \\
& -\left(k_{-5}^{\mathrm{H}^{+}}+k_{+5}^{\mathrm{OH}^{-}}\left[\mathrm{OH}^{-}\right]\right)\left[\mathrm{HCO}_{3}^{-}\right] \\
\frac{\mathrm{d}\left[\mathrm{CO}_{3}^{2-}\right]}{\mathrm{d} t}= & +\left(k_{-5}^{\mathrm{H}^{+}}+k_{+5}^{\mathrm{OH}^{-}}\left[\mathrm{OH}^{-}\right]\right)\left[\mathrm{HCO}_{3}^{-}\right] \\
& -\left(k_{+5}^{\mathrm{H}^{+}}\left[\mathrm{H}^{+}\right]+k_{-5}^{\mathrm{OH}^{-}}\right)\left[\mathrm{CO}_{3}^{2-}\right] \\
\frac{\mathrm{d}\left[\mathrm{H}^{+}\right]}{\mathrm{d} t}=+ & k_{+1}\left[\mathrm{CO}_{2}\right]-k_{-1}\left[\mathrm{H}^{+}\right]\left[\mathrm{HCO}_{3}^{-}\right] \\
+ & k_{-5}^{\mathrm{H}^{+}}\left[\mathrm{HCO}_{3}^{-}\right]-k_{+5}^{\mathrm{H}^{+}}\left[\mathrm{H}^{+}\right]\left[\mathrm{CO}_{3}^{2-}\right] \\
+ & k_{+6}+k_{-6}\left[\mathrm{H}^{+}\right]\left[\mathrm{OH}^{-}\right]+k_{+a}[\mathrm{AH}] \\
& -k_{-a}\left[\mathrm{H}^{+}\right]\left[\mathrm{A}^{-}\right]
\end{aligned}
$$


Table 1

Rate constants and their respective check values used in this study

\begin{tabular}{lll}
\hline Rate constant & Check value $T=298.15 \mathrm{~K}, S=35$ & Dependence on $T$ and $S$ \\
\hline$k_{+1}$ & $3.71 \times 10^{-2} \mathrm{~s}^{-1}$ & exp $\left(1246.98-6.19 \times 10^{4} / T-183.0 \mathrm{ln}(T)\right)$ \\
$k_{-1}$ & $2.67 \times 10^{4} \mathrm{~kg} \mathrm{~mol}^{-1} \mathrm{~s}^{-1}$ & $k_{+1} / K_{1}^{*}$ \\
$k_{+4}$ & $2.23 \times 10^{3} \mathrm{~kg} \mathrm{~mol}^{-1} \mathrm{~s}^{-1}$ & $A_{4} \exp (-90,166.83 /(R T)) / K_{\mathrm{W}}^{*}$ \\
$k_{-4}$ & $9.71 \times 10^{-5} \mathrm{~s}^{-1}$ & $k_{+4} \times K_{\mathrm{W}}^{*} / K_{1}^{*}$ \\
$k_{+5}^{\mathrm{H}^{+}}$ & $5.0 \times 10^{10} \mathrm{~kg} \mathrm{~mol}^{-1} \mathrm{~s}^{-1}$ & None \\
$k_{-5}^{\mathrm{H}^{+}}$ & $59.44 \mathrm{~s}^{-1}$ & $k_{+5}^{\mathrm{H}^{+}} \times K_{2}^{*}$ \\
$k_{+5}^{\mathrm{OH}-}$ & $6.0 \times 10^{9} \mathrm{~kg} \mathrm{~mol}^{-1} \mathrm{~s}^{-1}$ & Rone \\
$k_{-5}^{\mathrm{OH}-}$ & $3.06 \times 10^{5} \mathrm{~s}^{-1}$ & $k_{-5}^{\mathrm{OH}} \times K_{\mathrm{W}}^{*} / K_{2}^{*}$ \\
$k_{+6}$ & $1.40 \times 10^{-3} \mathrm{~mol} \mathrm{~kg}^{-1} \mathrm{~s}^{-1}$ & None \\
$k_{-6}$ & $2.31 \times 10^{-10} \mathrm{~kg} \mathrm{~mol}^{-1} \mathrm{~s}^{-1}$ & $k_{+6} / K_{\mathrm{W}}^{*}$ \\
$k_{+a}$ & $\mathrm{~s}^{-1}$ & $k_{-a} \times 10^{-\mathrm{p} K_{A}}$ \\
$k_{-a}$ & $\mathrm{~kg} \mathrm{~mol}^{-1} \mathrm{~s}^{-1}$ & $k_{+5}^{+} / f_{a}$
\end{tabular}

Ref. 1 refers to the work of Johnson (1982), while Ref. 2 refers to the work of Eigen (1964) (see Zeebe and Wolf-Gladrow (2001), p. 105 for a detailed discussion). $k_{+4}$ has been refitted in this study, with $A_{4}=499,002.24 \times \exp \left(4.2986 \times 10^{-4} S^{2}+5.75499 \times 10^{-5} S\right)$, with $S$ representing salinity because otherwise measured and calculated values for $k_{+}$did not match well, especially at high temperature. $\mathrm{p} K_{A}$ denotes the $\mathrm{p} K_{A}$ value of the $\mathrm{pH}$ buffer used, i.e. HEPES: $\mathrm{p} K=7.94-0.014 \times(T-273.15)$ and BICINE: $\mathrm{p} K=8.82-0.018 \times(T-273.15)$ after Good et al. (1966), with $T$ representing temperature in Kelvin. These are values extrapolated to zero ionic strength (see Beynon and Easterby (1996) for details). In the calculations, however, they have been adjusted to the correct ionic strength with the Davies approximation (Davies, 1962). Rate constants for the $\mathrm{pH}$ buffer were varied by applying a factor $f_{a}$ to $k_{-a} . R$ denotes the universal gas constant of $8.31451 \mathrm{~J} / \mathrm{mol}, K_{\mathrm{W}}^{*}$ the equilibrium constant for the ion product of water calculated after DOE (1994), and $K_{1}^{*}$ and $K_{2}^{*}$ the first and second dissociation constants of carbonic acid calculated according to Roy et al. (1993). The corresponding reactions for the different rate constants are listed in Eqs. (17)-(22).

$$
\begin{aligned}
\frac{\mathrm{d}\left[\mathrm{OH}^{-}\right]}{\mathrm{d} t}= & +k_{-4}\left[\mathrm{HCO}_{3}^{-}\right]-k_{+4}\left[\mathrm{OH}^{-}\right]\left[\mathrm{CO}_{2}\right] \\
& -k_{+5}^{\mathrm{OH}^{-}}\left[\mathrm{OH}^{-}\right]\left[\mathrm{HCO}_{3}^{-}\right]+k_{-5}^{\mathrm{OH}^{-}}\left[\mathrm{CO}_{3}^{2-}\right] \\
& +k_{+6}+k_{-6}\left[\mathrm{H}^{+}\right]\left[\mathrm{OH}^{-}\right]
\end{aligned}
$$

$\frac{\mathrm{d}[\mathrm{AH}]}{\mathrm{d} t}=+k_{-a}\left[\mathrm{H}^{+}\right]\left[\mathrm{A}^{-}\right]-k_{+a}[\mathrm{AH}]$

$\frac{\mathrm{d}\left[\mathrm{A}^{-}\right]}{\mathrm{d} t}=+k_{+a}[\mathrm{AH}]-k_{-a}\left[\mathrm{H}^{+}\right]\left[\mathrm{A}^{-}\right]$.

This set of coupled differential equations was integrated numerically with the matlab 'ode15s' solver for 'stiff' problems (Shampine and Reichelt, 1997). These equations are called 'stiff' because the coupled system exhibits extremely different relaxation times (Zeebe et al., 1999).

\section{3. pH-buffered seawater systems}

Relaxation times of the carbonate system in $\mathrm{pH}-$ buffered seawater upon disturbance depends on the type and amplitude of the disturbance and most importantly on the kinetics of the $\mathrm{pH}$ buffer. However, rate constants for the protonation and deprotonation of widely used $\mathrm{pH}$ buffers are not available, and a general assumption is that the two reactions are almost instantaneous or at least sufficiently fast compared to other reactions that they can be ignored. In the following considerations, the rate constants for the $\mathrm{pH}$ buffer (i.e., its speed) were chosen to be about 100 times slower than the comparatively rapid $\mathrm{CO}_{3}^{2-}$ to $\mathrm{HCO}_{3}^{-}$ interconversion.

\section{1. $\mathrm{K}_{2} \mathrm{CO}_{3}$ versus $\mathrm{CO}_{2}$ addition}

In Fig. 2 the response of the carbonate system upon addition of $\mathrm{K}_{2} \mathrm{CO}_{3}$ solution to low-DIC $\left(5 \mu \mathrm{mol} \mathrm{kg}{ }^{-1}\right)$, $\mathrm{pH}$-buffered seawater is shown (see caption of Fig. 2 for details). The amount of solution added was chosen to result in a $500 \mu \mathrm{mol} \mathrm{kg}^{-1}$ increase in DIC in the seawater sample. This setup resembles those previously used to determine $k_{-}$from the initial slope of $\mathrm{CO}_{2}$ evolution (e.g., Badger et al., 1994; Sültemeyer et al., 1995). The re-equilibration in the carbonate system following the addition of a $\mathrm{K}_{2} \mathrm{CO}_{3}$ solution includes three characteristic time scales.

\subsubsection{Time scale $10^{-10}$ to $10^{-5} \mathrm{~s}$}

Injection of a highly alkaline $\mathrm{K}_{2} \mathrm{CO}_{3}$ solution ( $\mathrm{pH} \sim 11$ ) into seawater of $\mathrm{pH} 8$ significantly increases the $\mathrm{OH}^{-}$concentration as illustrated by the drop in pOH, i.e., the negative common logarithm of $\left[\mathrm{OH}^{-}\right]$ in analogy to $\mathrm{pH}$ (Fig. 2E). This decrease in $\mathrm{pOH}$ leads to an immediate increase in $\mathrm{pH}$ (Fig. $2 \mathrm{~F}$ ) as the $\mathrm{OH}^{-}$ added consumes the $\mathrm{H}^{+}$present. Also shortly after injection of the $\mathrm{K}_{2} \mathrm{CO}_{3}$ solution, the conversion of the 

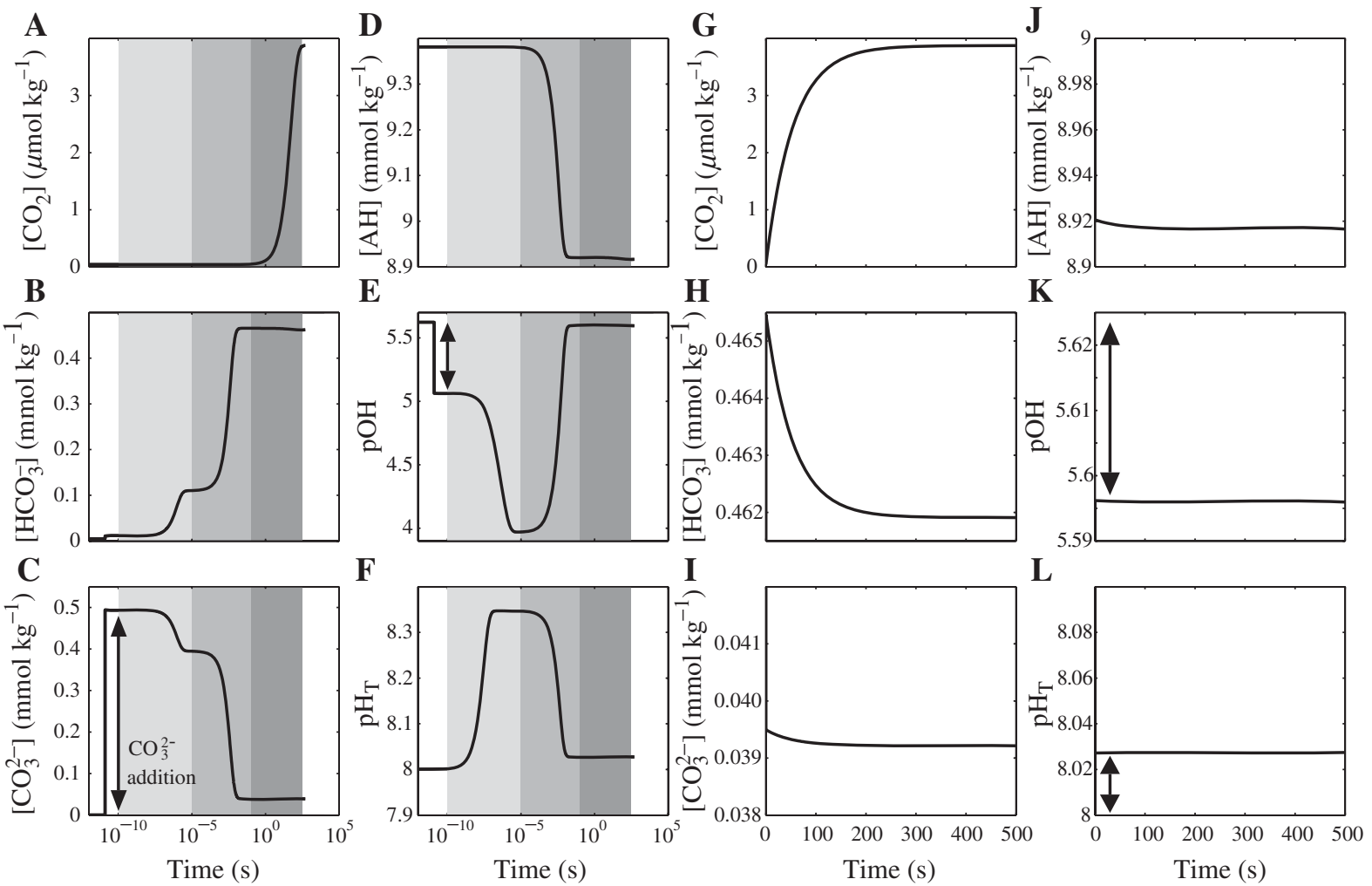

Fig. 2. Reaction kinetics in pH-buffered seawater upon addition of a $\mathrm{K}_{2} \mathrm{CO}_{3}$ solution (at $t$ equals zero), leading to an increase in DIC of $500 \mu \mathrm{mol} \mathrm{kg}{ }^{-1}$ in the seawater sample, as calculated by the numerical model described in Section 2.4. The pH buffer was set to $50 \mathrm{mM}$ of HEPES, temperature to $15{ }^{\circ} \mathrm{C}$, Salinity to $35, \mathrm{pH}$ to 8.0 , initial DIC to $5 \mu \mathrm{mol} \mathrm{kg}{ }^{-1}$ and $k_{-\mathrm{a}}$ to $k_{+5}^{\mathrm{H}^{+}} / 100$. AH denotes the protonated form of the buffer. Illustrated in $\mathrm{A}-\mathrm{F}$ are the changes of $\left[\mathrm{CO}_{2}\right],\left[\mathrm{HCO}_{3}^{-}\right],\left[\mathrm{CO}_{3}^{2-}\right],[\mathrm{AH}], \mathrm{pOH}$ and $\mathrm{pH}$ (on the total scale) against time on a logarithmic scale, while in $\mathrm{G}-\mathrm{L}$ the same reactions against time are shown on a linear scale. Grey shaded areas depict different timescales ranging from $10^{-10}$ to $10^{-5}, 10^{-5}$ to $10^{-1}$ and $10^{-1}$ to 400 seconds (light, intermediate and dark grey, respectively). The arrows denote changes from equilibrium due to the disturbance by the addition of a $\mathrm{K}_{2} \mathrm{CO}_{3}$ solution.

added $\mathrm{CO}_{3}^{2-}$ to $\mathrm{HCO}_{3}^{-}$begins (Fig. 2B,C). In this reaction $\mathrm{CO}_{3}^{2-}$ combines with water giving $\mathrm{HCO}_{3}^{-}$and $\mathrm{OH}^{-}$ (compare Eq. (20)) leading to a concomitant decrease in pOH (Fig. 2E). Why this reaction is dominating rather than the competing one, in which $\mathrm{CO}_{3}^{2-}$ combines with $\mathrm{H}^{+}$(Eq. (19)), can easily be understood by comparing the relevant terms, $k_{-5}^{\mathrm{OH}^{-}}$and $k_{+5}^{\mathrm{H}^{+}}\left[\mathrm{H}^{+}\right]$, in Eq. (25). As $k_{-5}^{\mathrm{OH}^{-}}$is about seven orders of magnitude larger than $k_{+5}^{\mathrm{H}_{5}^{+}}\left[\mathrm{H}^{+}\right], \mathrm{HCO}_{3}^{-}$is formed almost entirely by the combination of $\mathrm{CO}_{3}^{2-}$ with water. The decrease in $\mathrm{pOH}$ is not a mirror image of the increase in $\mathrm{pH}$, indicating that the ion product of water (Eq. (21)) is not constant on this time scale. The reason is that the conversion of $\mathrm{CO}_{3}^{2-}$ to $\mathrm{HCO}_{3}^{-}$is slightly faster than the combination reaction of $\mathrm{H}^{+}$and $\mathrm{OH}^{-}$. Hence, the increase in $\mathrm{pH}$ lags behind the decrease in $\mathrm{pOH}$. Furthermore, the protonated form of the $\mathrm{pH}$ buffer is already starting to release protons to compensate for the loss of $\mathrm{H}^{+}$, dampening the increase in $\mathrm{pH}$. This initial $\mathrm{pH}$-buffering, however, is not visible in
[AH] (Fig. 2D) as the amount of $\mathrm{H}^{+}$released by the protonated form of the buffer is about six orders of magnitude lower than the buffer's concentration (note that $\left[\mathrm{H}^{+}\right]$is in the nanomolar and $[\mathrm{AH}]$ in millimolar range). A temporary $\mathrm{pH}$ plateau of about 8.35 is reached after about $10^{-6} \mathrm{~s}$. The height of this plateau depends on the rate constants of the $\mathrm{pH}$ buffer chosen. Increasing the rate constants increases the speed of the buffer and the temporary plateau will be closer to the final equilibrium value of about $\mathrm{pH} 8.0$.

\subsubsection{Time scale $10^{-5}$ to $10^{-1} \mathrm{~s}$}

The comparatively massive proton release by the protonated form of the buffer (Fig. 2D) yields to both, an increase of $\mathrm{pOH}$ (due to protonation of $\mathrm{OH}^{-}$) and a decrease of $\mathrm{pH}$ (Fig. 2E,F). Hence, a second phase of $\mathrm{CO}_{3}$ to $\mathrm{HCO}_{3}^{-}$conversion is initiated (Fig. 2B,C). A temporary quasi steady-state between all these pools is established after about $10^{-2}$ s (Fig. 2B-F). 


\subsubsection{Time scale larger than $10^{-1} \mathrm{~s}$}

It is by now that the $\mathrm{HCO}_{3}^{-}$and $\mathrm{CO}_{2}$ pools start to reequilibrate (Fig. 2A,B), owing to the slow interconversion rate. Again, the protonated form of the $\mathrm{pH}$-buffer re-delivers the protons consumed by the conversion of $\mathrm{HCO}_{3}^{-}$to $\mathrm{CO}_{2}$ (Fig. 2D). However, as the $\mathrm{pH}$-buffer was assumed orders of magnitude faster than the $\mathrm{HCO}_{3}^{-}$to $\mathrm{CO}_{2}$ conversion and the amount of protons released is small compared to those released due to the conversion of $\mathrm{CO}_{3}^{2-}$ to $\mathrm{HCO}_{3}^{-}$, the $\mathrm{pH}$ and the $\mathrm{pOH}$ stay constant during this last phase of re-equilibration.

In this configuration (see caption of Fig. 2 for details), the $\mathrm{pH}$-buffer was able to keep the $\mathrm{pH}$ constant on a time scale of seconds (Fig. 2L), which is a prerequisite for the fitting procedure. However, it is obvious that this depends on the actual rate constants assumed for the protonation/deprotonation reactions of the buffer (i.e., its speed). When adding a $\mathrm{K}_{2} \mathrm{CO}_{3}$ solution to a seawater system as described above, the $\mathrm{pH}$ buffer has to release far more protons consumed in the rapid conversion of $\mathrm{CO}_{3}^{2-}$ to $\mathrm{HCO}_{3}^{-}$than from the slow reaction of $\mathrm{HCO}_{3}^{-}$to $\mathrm{CO}_{2}$.
This is opposite to addition of a $\mathrm{CO}_{2}$ solution (Fig. 3 ), where the $\mathrm{pH}$ buffer has to accept more protons from the slow reaction. Again, there are three characteristic time scales for the re-equilibration.

\subsubsection{Time scale $10^{-10}$ to $10^{-5} \mathrm{~s}$}

Injection of a $\mathrm{CO}_{2}$ solution, yielding a final DIC concentration of $500 \mu \mathrm{mol} \mathrm{kg} \mathrm{kg}^{-1}$, in the buffered seawater (the preparation of such solution is described in Section 2.1), causes an initial drop in $\mathrm{pH}$ (Fig. 3F) as such a solution is highly acidic $(\mathrm{pH} \sim 3.8)$. Almost instantly the unprotonated form of the buffer starts to accept the $\mathrm{H}^{+}$added, leading to an increase in $\mathrm{pH}$ and [AH], the protonated form of the buffer (Fig. 3D). Please note that the total increase in $\mathrm{pH}$ from about 5.5 to 8.0 corresponds to a decrease in $\left[\mathrm{H}^{+}\right]$of about $3 \mu \mathrm{mol} \mathrm{kg}{ }^{-1}$. This is difficult to detect in the simultaneous increase in $[\mathrm{AH}]$ as, again, the buffer concentration is about four orders of magnitude higher than the amount of protons accepted. $\mathrm{pH}$ reaches a temporary plateau of about 8.0 already before $10^{-5} \mathrm{~s}$. The time required to achieve this $\mathrm{pH}$ which is close to equilibrium conditions crucially
A

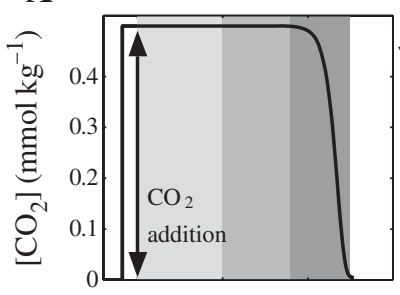

B

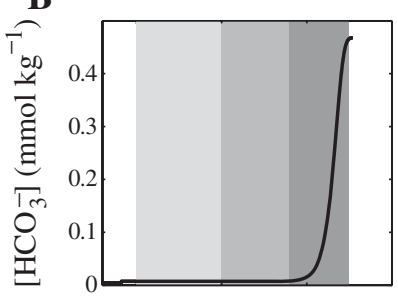

C

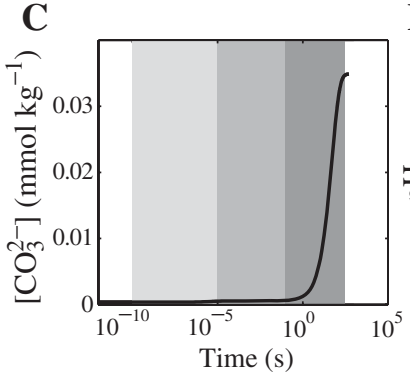

D

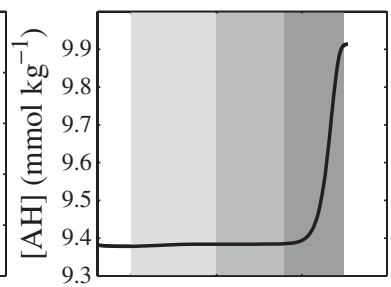

E

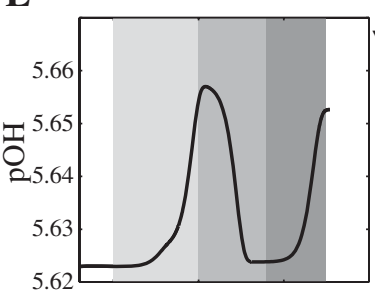

F

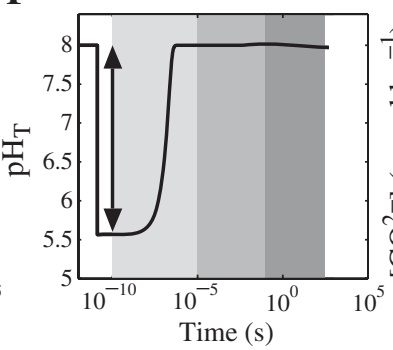

G

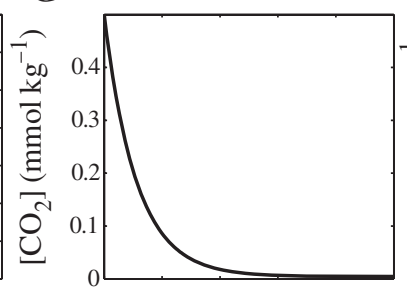

H

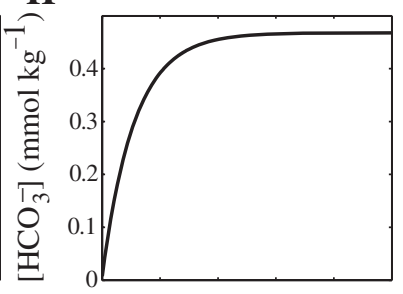

I

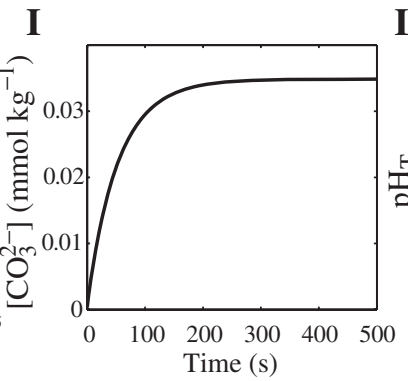

$\mathbf{J}$

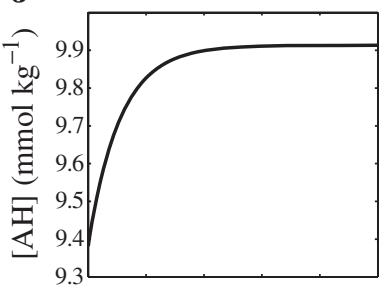

$\mathbf{K}$

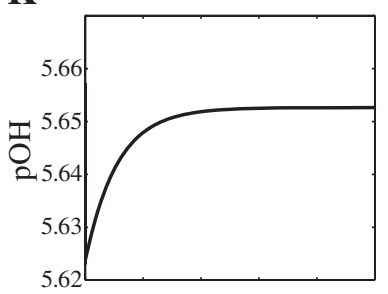

$\mathbf{L}$

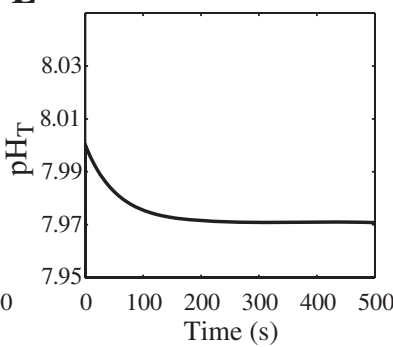

Fig. 3. Reaction kinetics in $\mathrm{pH}$-buffered seawater upon addition of a $\mathrm{CO}_{2}$ solution (at $t$ equals zero), leading to an increase in $\mathrm{DIC}$ of $500 \mu \mathrm{mol} \mathrm{kg}^{-1}$ in the seawater sample, as calculated by the numerical model described in Section 2.4. For details see Fig. 2 caption. 
depends on the rate constants of the buffer, i.e., its speed. Already shortly after the initial increase in $\mathrm{pH}$ there is an increase in pOH. This is partly caused by the combination of $\mathrm{HCO}_{3}^{-}$with $\mathrm{OH}^{-}$yielding $\mathrm{CO}_{3}^{2-}$ (Eq. (20)) because the injected $\mathrm{CO}_{2}$ solution contains a small amount of $\mathrm{HCO}_{3}^{-}\left(\sim 2.5 \mu \mathrm{mol} \mathrm{kg}{ }^{-1}\right)$. Hence, part of the $\mathrm{HCO}_{3}^{-}\left(\sim 0.2 \mu \mathrm{mol} \mathrm{kg}{ }^{-1}\right)$ added convert to $\mathrm{CO}_{3}^{2-}$ resulting in the increase in $\mathrm{pOH}$. Also responsible for the increase in $\mathrm{pOH}$ is the combination of the $\mathrm{H}^{+}$added with the $\mathrm{OH}^{-}$present. However, the increase in $\mathrm{pOH}$ is not as pronounced as the increase in $\mathrm{pH}$, indicating that the ion product of water on this time scale is not constant. This can be easily understood when comparing the equations competing for the $\mathrm{H}^{+}$ added which are the formation of water with $\mathrm{OH}^{-}$(Eq. (21)) and the combination with the unprotonated form of the buffer $\mathrm{A}^{-}$(Eq. (22)). The relevant terms for these reactions given in Eq. (26) are $k_{-6}\left[\mathrm{OH}^{-}\right]$and $k_{-\mathrm{a}}\left[\mathrm{A}^{-}\right]$, respectively (note that $\left[\mathrm{H}^{+}\right]$is the same for both of them). As $k_{-\mathrm{a}}\left[\mathrm{A}^{-}\right]$, is about 200 times larger than $k_{-6}\left[\mathrm{OH}^{-}\right]$the increase in $\mathrm{pH}$ is dominated by the protonation of the buffer and not by $\mathrm{OH}^{-}$consumption. Hence, the increase in $\mathrm{pH}$ is hardly reflected in $\mathrm{pOH}$.

\subsubsection{Time scale $10^{-5}$ to $10^{-1} \mathrm{~s}$}

The imbalance between the $\mathrm{OH}^{-}$and $\mathrm{H}^{+}$pools start to re-equilibrate and the $\mathrm{pOH}$ drops to its initial value whereas the $\mathrm{pH}$ is kept constant by the buffer. Again, a temporary quasi steady-state between all these pools is established after about $10^{-2}$ s (Fig. 3B-F).

\subsubsection{Time scale larger than $10^{-1} \mathrm{~s}$}

The slow conversion reaction of $\mathrm{CO}_{2}$ to $\mathrm{HCO}_{3}^{-}$is then initiated at about $10^{-1} \mathrm{~s}$ leading to a slight drop in $\mathrm{pH}$ and a concomitant increase in $\mathrm{pOH}$ compared to conditions prior to injection. And again, in this configuration (see caption of Fig. 3 for details) the buffer has been able to keep the $\mathrm{pH}$ very close to equilibrium values (Fig. 3L). Basically, if the protonation reaction of the buffer is faster than the conversion of $\mathrm{CO}_{2}$ to $\mathrm{HCO}_{3}^{-}$it can keep up with the release of protons by this process.

\subsection{Influence of the $p H$ buffer kinetics on changes in $\mathrm{pH}$}

As outlined above, a prerequisite for fitting of the $\mathrm{CO}_{2}$ evolution curve upon addition of a $\mathrm{K}_{2} \mathrm{CO}_{3}$ or $\mathrm{CO}_{2}$ solution (Figs. 2G and 3G, respectively) is that the $\mathrm{pH}$ can be considered constant. The rate constants for the protonation and deprotonation of certain $\mathrm{pH}$ buffers, however, are not known. Therefore, their influence on
$\mathrm{pH}$, following the addition of $\mathrm{K}_{2} \mathrm{CO}_{3}$ or $\mathrm{CO}_{2}$ solution, was investigated by varying the rate constants of the $\mathrm{pH}$ buffer in the seawater carbonate system model. More specifically, the time was determined after which the $\mathrm{pH}$ reached a constant value. For that, a critical threshold was introduced of $0.05 \mathrm{pH}$ units which was the maximum $\mathrm{pH}$ drift from steady state conditions after injection of a $\mathrm{K}_{2} \mathrm{CO}_{3}$ or $\mathrm{CO}_{2}$ solution, observed in all measurements. Calculated times to reach that threshold depend to a small degree on whether $\mathrm{K}_{2} \mathrm{CO}_{3}$ or $\mathrm{CO}_{2}$ is added (Fig. 4A/B), but mostly on the $\mathrm{pH}$ of the seawater. The differences in $\mathrm{pK}$ values between HEPES and BICINE are negligible for the following considerations. The time to reach constant $\mathrm{pH}$ values is faster the lower the $\mathrm{pH}$ is regardless whether $\mathrm{K}_{2} \mathrm{CO}_{3}$ (Fig. $4 \mathrm{~A}$ ) or $\mathrm{CO}_{2}$ (Fig. 4B) is added. When adding $\mathrm{K}_{2} \mathrm{CO}_{3}$ the protonated form of the $\mathrm{pH}$ buffer $(\mathrm{AH})$ releases protons to compensate for the loss of $\mathrm{H}^{+}$consumed by the conversion of $\mathrm{CO}_{3}^{2-}$ to $\mathrm{HCO}_{3}^{-}$. Hence, at low $\mathrm{pH}$ the initial concentration of $\mathrm{AH}$ is higher compared to high $\mathrm{pH}$ and the re-equilibration is faster. On the other hand, when adding $\mathrm{CO}_{2}$ the unprotonated form of the buffer accepts the protons generated by the conversion of $\mathrm{CO}_{2}$ to $\mathrm{HCO}_{3}^{-}$. Hence at low $\mathrm{pH}$, this protonation is enhanced by the increased $\left[\mathrm{H}^{+}\right]$.

It seems that neither $\mathrm{K}_{2} \mathrm{CO}_{3}$ nor $\mathrm{CO}_{2}$ addition bears any advantages for measuring the carbon dioxide to bicarbonate interconversion rates. However, the time to reach constant $\mathrm{pH}$ values is not only bound to buffer kinetics but also to the amplitude of the disturbance. Basically, the lower the amount of $\mathrm{K}_{2} \mathrm{CO}_{3}$ or $\mathrm{CO}_{2}$ addition, the lower is the disequilibrium in $\left[\mathrm{H}^{+}\right]$the buffer has to cope with. Injecting a small amount of $\mathrm{CO}_{2}$ and measuring its disappearance into the $\mathrm{HCO}_{3}^{-}$ and $\mathrm{CO}_{3}^{2-}$ pools is possible, while the same amount injected as $\mathrm{K}_{2} \mathrm{CO}_{3}$ will result in almost no detectable change in $\left[\mathrm{CO}_{2}\right]$ (note that in seawater, with a $\mathrm{pH}$ ranging from 7-9, the dominant DIC form is $\mathrm{HCO}_{3}^{-}$ while the MIMS is only able to detect $\mathrm{CO}_{2}$ and the two other DIC species have to be deduced). This is illustrated in Figs. $3 \mathrm{~A}$ and $2 \mathrm{~A}$, where the change in $\left[\mathrm{CO}_{2}\right]$ due to a $500 \mu \mathrm{mol} \mathrm{kg}{ }^{-1}$ addition of $\mathrm{CO}_{2}$ is about $500 \mu \mathrm{mol} \mathrm{kg} \mathrm{kg}^{-1}$, while the addition of $500 \mu \mathrm{mol}$ $\mathrm{kg}^{-1}$ of $\mathrm{K}_{2} \mathrm{CO}_{3}$ results in a change in $\left[\mathrm{CO}_{2}\right]$ of only about $4 \mu \mathrm{mol} \mathrm{kg}{ }^{-1}$. Therefore, it is feasible to work with much lower additions of $\mathrm{CO}_{2}$ compared to $\mathrm{K}_{2} \mathrm{CO}_{3}$, and the influence of the buffer kinetics on the time to reach constant $\mathrm{pH}$ values is becoming less critical (when adding $15 \mu \mathrm{mol} \mathrm{kg}{ }^{-1}$ of $\mathrm{CO}_{2}$ instead of $500 \mu \mathrm{mol} \mathrm{kg}^{-1}$ (compare Fig. 4A) the $\mathrm{pH}$ is constant from the first second, regardless of seawater $\mathrm{pH}$ and buffer kinetics). Hence, the experiments were carried 
A

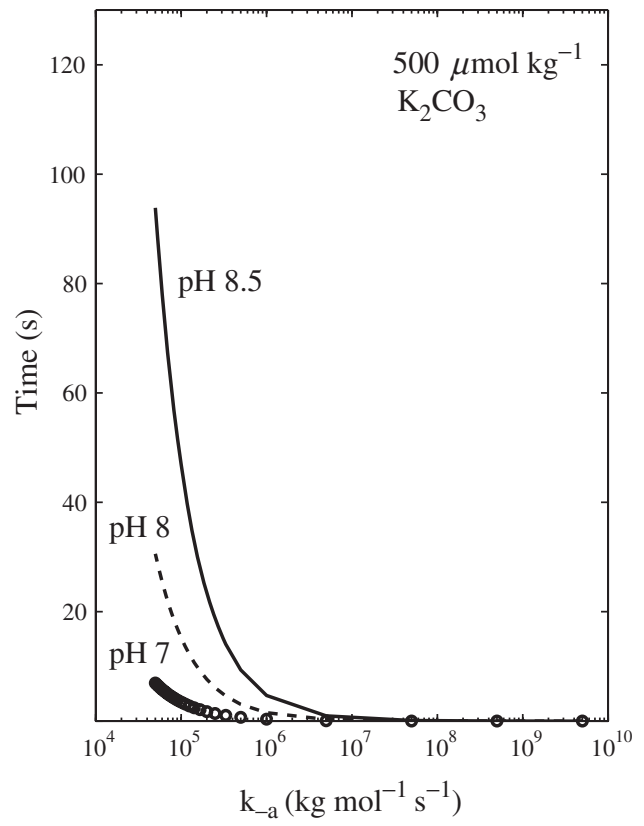

B

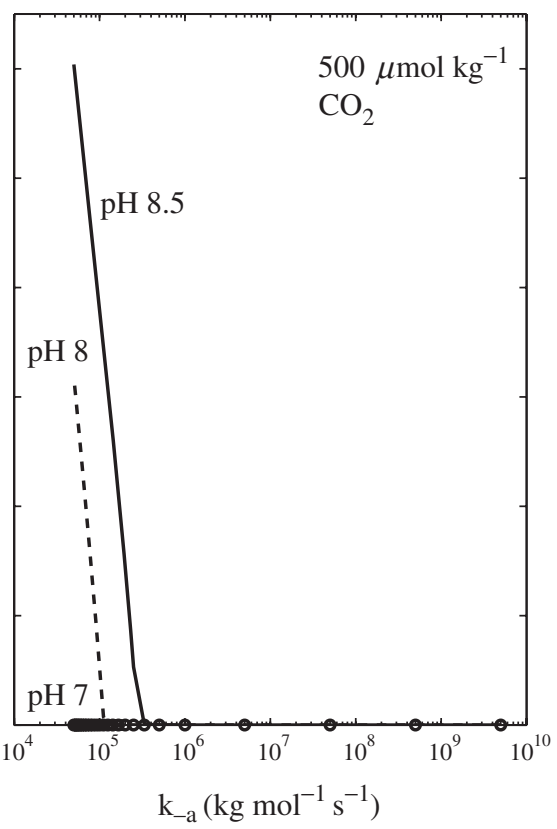

Fig. 4. Influence of the $\mathrm{pH}$ buffer kinetics on the $\mathrm{pH}$ re-equilibration time as predicted by the numerical model described in Section 2.4 . The $\mathrm{pH}$

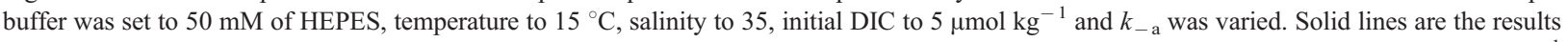
for a seawater $\mathrm{pH}$ of 8.5 , dashed lines for a $\mathrm{pH}$ of 8.0 and circles for a $\mathrm{pH}$ of 7.0. Illustrated in $\mathrm{A}$ are the results upon an addition of $500 \mu \mathrm{mol} \mathrm{kg}^{-1}$ $\mathrm{K}_{2} \mathrm{CO}_{3}$ and in $\mathrm{B}$ the results upon an addition of $500 \mu \mathrm{mol} \mathrm{kg}{ }^{-1} \mathrm{CO}_{2}$.

out with small amounts of $\mathrm{CO}_{2}$ injected into seawater buffered at different $\mathrm{pH}$ values at certain temperatures, and the resulting decrease in $\left[\mathrm{CO}_{2}\right]$ was monitored and fitted with Eq. (16) (Fig. 1).

\subsection{The rate constants for $\mathrm{CO}_{2}$ to $\mathrm{HCO}_{3}^{-}$interconver- sion at different temperatures and $\mathrm{pH}$}

The $k_{+}$values resulting from fitting the $\mathrm{CO}_{2}$ evolution upon adding small amounts of $\mathrm{CO}_{2}$ (yielding a final concentration of about $15 \mu \mathrm{mol} \mathrm{kg}{ }^{-1}$ ) to seawater buffered at $\mathrm{pH}$ values ranging from 7 to 9 and temperatures of 11,16 and $26{ }^{\circ} \mathrm{C}$ are shown in Fig. 5. Also shown are calculated $k_{+}$values from the second part of Eq. (23) with $k_{+}=k_{+1}+k_{+4}\left[\mathrm{OH}^{-}\right]$, the combination of reactions (17) and (18) (see Appendix for details). Because application of $k_{+4}$ values, determined previously (Zeebe and Wolf-Gladrow, 2001) by fitting the original data from Johnson (1982), did not match the measurements (especially at $26{ }^{\circ} \mathrm{C}$ ), $k_{+4}$ has been refitted in this study (see Table 1 for details). Measured and calculated $k_{+}$values are in good agreement in the $\mathrm{pH}$ range from 7 to 8.5 , regardless whether HEPES or BICINE was used as $\mathrm{pH}$ buffer. This clearly indicates that both buffers are able to keep the $\mathrm{pH}$ constant under the experimental conditions tested. Above a $\mathrm{pH}$ of 8.5 , however, correlation between measured and calculated values becomes less clear. One reason is that the error in $\mathrm{pH}$ determination with the MIMS increases with rising $\mathrm{pH}$, because the contribution of $\mathrm{CO}_{2}$ to DIC decreases. Hence, after additions of known amounts of $\mathrm{NaHCO}_{3}$ to determine the $\mathrm{DIC} / \mathrm{CO}_{2}$ ratio, the change in $\left[\mathrm{CO}_{2}\right]$ will get close to the noise in the $\mathrm{CO}_{2}$ signal detected by the MIMS. Under these circumstances the $\mathrm{pH}$ cannot be calculated reliably anymore.

Furthermore, $k_{+}$increases with rising temperature and $\mathrm{pH}$ (Fig. 5). High $\mathrm{pH}$ values correspond to increased $\left[\mathrm{OH}^{-}\right]$and therefore the reaction of $\mathrm{CO}_{2}+\mathrm{OH}^{-} \rightarrow \mathrm{HCO}_{3}^{-}$is faster compared to low $\mathrm{pH}$ and $k_{+}$is larger. Strictly speaking, the $\mathrm{CO}_{2}$ evolution is characterized not by $k_{+}$alone, but by $\gamma k_{+}$(see Eq. (16)). But at $\mathrm{pH}$ values above $7, \gamma=R /(R-1)$ is almost equal to one and can be neglected (also compare solid line in Fig. 5 with Fig. 6A) From equilibrium conditions described in Eq. (1), it follows that $k_{-}=k_{+} / K_{1}^{*}$.

From Fig. 1 it becomes evident that interpretation of initial $\mathrm{CO}_{2}$ slopes recorded by the MIMS is difficult. This is due to the fact that in the first couple of seconds, following a disturbance, homogeneous mixing in the cuvette and changing gas fluxes through the membrane 


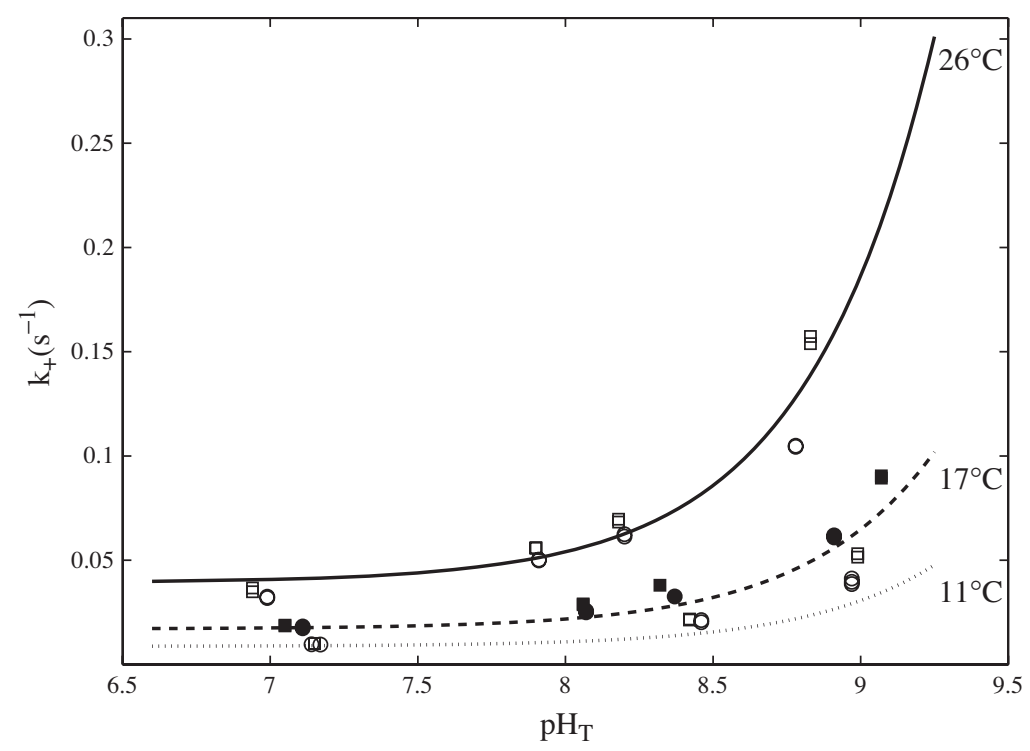

Fig. 5. Graphical illustration of the $k_{+}$values determined with the fitting procedure shown in Fig. 1 and described in Section 2.3 , measured by additions of $\sim 15 \mu \mathrm{mol} \mathrm{kg}{ }^{-1} \mathrm{CO}_{2}$ at different temperatures and seawater $\mathrm{pH}$ (total scale). Squares denote seawater buffered with $50 \mathrm{mM} \mathrm{HEPES}$ and circles seawater with $50 \mathrm{mM}$ BICINE. The lines depict calculated $k_{+}$with $k_{+}=k_{+1}+k_{+4}\left[\mathrm{OH}^{-}\right]$(see Table 1 for details regarding the rate constants) at temperatures of 11 (dotted), 17 (dashed) and $26{ }^{\circ} \mathrm{C}$ (solid line).

mask the kinetics in the carbonate system. Thus, the initial slope of the $\mathrm{CO}_{2}$ evolution curve (defined as the maximum slope) is always shallower than the slope that would be observed in an ideal setup. This can only be accounted for by fitting the $\mathrm{CO}_{2}$ signal from the inflec- tion point to a suitable equation, which explicitly incorporates the forward and backward reactions between the $\mathrm{CO}_{2}$ and $\mathrm{HCO}_{3}^{-}$pools. Hence, determination of $k_{-}$ from the initial slope as proposed previously underestimates $k_{-}$(and therefore $k_{+}$). We estimate this error
A

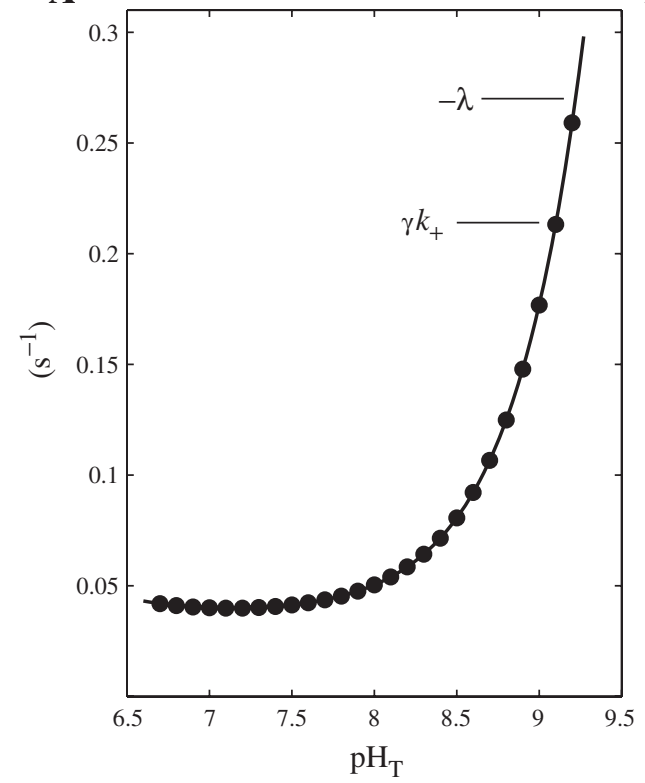

B

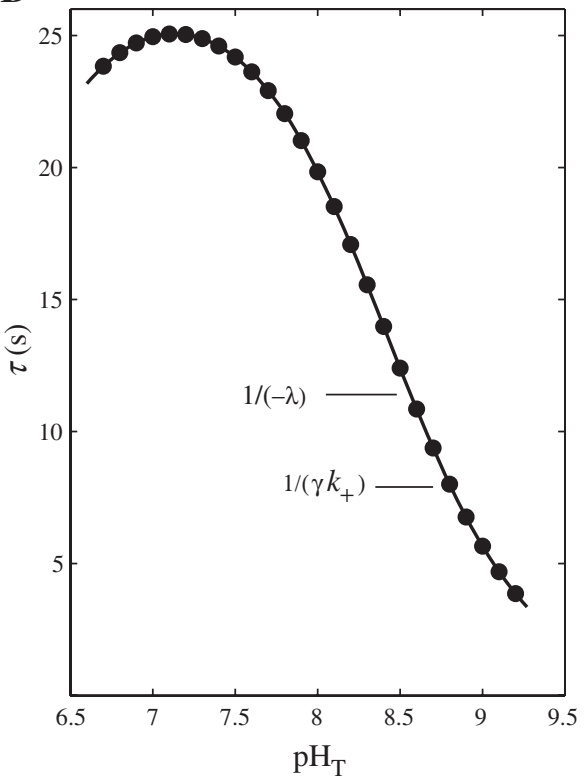

Fig. 6. Comparison of $\gamma k_{+}$(dots), with $k_{+}$calculated as for Fig. 5, and the eigenvalues $\lambda$ of the carbonate system (solid line) described in Section 3.4 at $25^{\circ} \mathrm{C}$ at a salinity of 35 between $\mathrm{pH} 7$ and 9 . A compares $\gamma k_{+}$with $\lambda$ while B illustrates the inverse of these values, which are the relaxation times $\tau$ of the carbonate system upon disturbance. 
to be up to $50 \%$ depending on temperature, $\mathrm{pH}$ and MIMS setup.

\subsection{Theoretical remarks on $k_{+}=k_{+1}+k_{+4}\left[\mathrm{OH}^{-}\right]$}

It can be shown that the conversion of $\mathrm{CO}_{2}$ to $\mathrm{HCO}_{3}^{-}$on time scales monitored by the MIMS (i.e., seconds) is given by the slowest process, which is characterized by the relaxation time $\tau$ :

$$
\begin{aligned}
\tau= & -\frac{1}{\lambda} \\
\lambda= & -\frac{1}{2}\left(k_{-}+k_{+}+\bar{k}_{-}+\bar{k}_{+}\right) \\
& +\frac{1}{2} \sqrt{\left(k_{-}+k_{+}-\bar{k}_{-}-\bar{k}_{+}\right)^{2}+4 k_{-} \bar{k}_{-}},
\end{aligned}
$$

with $k_{-}=k_{-1}\left[\mathrm{H}^{+}\right]+k_{-4}, k_{+}=k_{+1}+k_{+4}\left[\mathrm{OH}^{-}\right], \bar{k}_{-}=k_{-5}^{\mathrm{H}^{+}}+$ $k_{+5}^{\mathrm{OH}^{-}}\left[\mathrm{OH}^{-}\right]$, and $\bar{k}_{+}=k_{+5}^{\mathrm{H}^{+}}\left[\mathrm{H}^{+}\right]+k_{-5}^{\mathrm{OH}^{-}}$. Because of the rapid interconversion of $\mathrm{HCO}_{3}^{-}$and $\mathrm{CO}_{3}^{2-}$, the exact solution for $\left[\mathrm{CO}_{2}\right](t)$ at constant $\mathrm{pH}$ can excellently be approximated by Eq. (16), with

$\tau \approx \frac{1}{\gamma k_{+}}$.

as shown in Fig. 6B.

In summary, if the $\mathrm{pH}$ buffer is able to keep the $\mathrm{pH}$ constant upon disturbance in the carbonate system, the rate constants for the $\mathrm{CO}_{2}$ to $\mathrm{HCO}_{3}^{-}$interconversion, $k_{+}$ and $k_{-}$, can be calculated as $k_{+}=k_{+1}+k_{+4}\left[\mathrm{OH}^{-}\right]$and $k_{-}=k_{+} K_{1}^{*}$ (see Table 1 for details on the rate constants).

\section{Summary and conclusions}

Mass spectrometric and ${ }^{14} \mathrm{C}$ disequilibrium techniques are widely used to assess modes and efficiencies of inorganic carbon acquisition in marine phytoplankton (Badger et al., 1994; Espie and Colman, 1986). These methods rely on the exact knowledge of the rate constants for the $\mathrm{CO}_{2}$ to $\mathrm{HCO}_{3}^{-}$interconversion reaction, which depend on $\mathrm{pH}$, temperature and salinity. In this study, a method is presented for measuring these rate constants, known as $k_{+}$and $k_{-}$, by means of membrane inlet mass spectrometry (MIMS). For the two $\mathrm{pH}$ buffers tested (HEPES and BICINE) it was shown that measured rate constants are in good agreement with calculated values for $k_{+}$and $k_{-}$in a $\mathrm{pH}$ range of 7 to 8.5 and at temperatures from 10 to $25{ }^{\circ} \mathrm{C}$. Moreover, it was shown that the method proposed previously to determine the $\mathrm{CO}_{2}$ to $\mathrm{HCO}_{3}^{-}$interconversion rate constants tends to significantly underestimate them. Therefore, it is recommended that in future applications $k_{+}$and $k_{-}$are measured or calculated as described above.

\section{Acknowledgements}

We thank K.-U. Richter for technical assistance and A. Körtzinger for vital discussions regarding the carbonate system. This work was funded by the Deutsche Forschungsgemeinschaft (DFG) project \#TH 744/2-1.

\section{Appendix A}

The reaction scheme for the hydration of carbon dioxide can be formulated as (cf. Eigen et al. (1961))

(I)

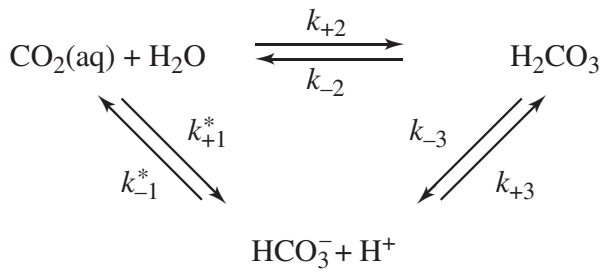

(III)

in which aqueous carbon dioxide $\left(\mathrm{CO}_{2}(\mathrm{aq})\right)$ is either hydrated in the transition of (I) to (III) or via $\mathrm{H}_{2} \mathrm{CO}_{3}$ in the transition of (I) to (II) to (III). The overall hydration and dehydration reaction as measured by Johnson (1982) is then given as

$\mathrm{CO}_{2}+\mathrm{H}_{2} \mathrm{O} \underset{k_{-1}}{\stackrel{k_{+1}}{\rightleftharpoons}} \mathrm{H}^{+}+\mathrm{HCO}_{3}^{-}$

$(\mathrm{A}-1)$

with $\mathrm{CO}_{2}$ denoting the sum of $\mathrm{CO}_{2}(\mathrm{aq})$ and $\mathrm{H}_{2} \mathrm{CO}_{3}$, and $k_{+1}$ and $k_{-1}$ being the effective rate constants. As the reaction between carbonic acid and bicarbonate (II) $\leftrightharpoons$ (III) is diffusion-controlled, it is practically instantaneous and equilibrium can be assumed as

$\left[\mathrm{H}^{+}\right]\left[\mathrm{HCO}_{3}^{-}\right]=K_{\mathrm{H}_{2} \mathrm{CO}_{3}}^{*}\left[\mathrm{H}_{2} \mathrm{CO}_{3}\right]$

$(\mathrm{A}-2)$

with $K_{\mathrm{H}_{2} \mathrm{CO}_{3}}^{*}$ being the acidity constant of true carbonic acid. Hence, $k_{+1}$ and $k_{-1}$ of the overall hydration/ dehydration reaction are given by

$k_{+1}:=k_{+1}^{*}+k_{+2}$

$(\mathrm{A}-3)$

and

$k_{-1}:=k_{-1}^{*}+\frac{k_{-2}}{K_{\mathrm{H}_{2} \mathrm{CO}_{3}}^{*}}$ 
While the hydration/dehydration reaction is dominant at low $\mathrm{pH}$, at high $\mathrm{pH}$ the reaction via hydroxylation is favored as

$$
\mathrm{CO}_{2}+\mathrm{OH}^{-} \underset{k_{-4}}{\stackrel{k_{+4}}{\rightleftharpoons}} \mathrm{HCO}_{3}^{-}
$$

The combination of the hydration/dehydration and the hydroxylation reaction gives the overall interconversion reaction of $\mathrm{CO}_{2}$ to $\mathrm{HCO}_{3}^{-}$and vice versa as

$\mathrm{H}_{2} \mathrm{O}+\mathrm{CO}_{2} \underset{k_{-}}{\stackrel{k_{+}}{\rightleftharpoons}} \mathrm{HCO}_{3}^{-}+\mathrm{H}^{+}$

with

$k_{+}:=k_{+1}+k_{+4}\left[\mathrm{OH}^{-}\right]$

and

$k_{-}:=k_{-1}\left[\mathrm{H}^{+}\right]+k_{-4}$

Note that the overall reaction (Eq. (A-6)) must not be confused with that given Eq. (A-1) as it incorporates also the hydroxylation pathway.

\section{References}

Badger, M.R., Palmqvist, K., Yu, J.-W., 1994. Measurement of $\mathrm{CO}_{2}$ and $\mathrm{HCO}_{3}^{-}$fluxes in cyanobacteria and microalgae during steadystate photosynthesis. Physiol. Plant. 90, 529-536.

Beynon, R.J., Easterby, J.S., 1996. Buffer Solutions: The Basics. Oxford University Press.

Burkhardt, S., Amoroso, G., Riebesell, U., Sültemeyer, D., 2001. $\mathrm{CO}_{2}$ and $\mathrm{HCO}_{3}^{-}$uptake in marine diatoms acclimated to different $\mathrm{CO}_{2}$ concentrations. Limnol. Oceanogr. 46, 1378-1391.

Cooper, T.G., Filmer, D., Wishnick, M., Lane, M.D., 1969. The active species of " $\mathrm{CO}_{2}$ " utilized by riboluse diphosphate carboxylase. J. Biol. Chem. 244, 1081-1083.

Davies, C.W., 1962. Ion Association. Butterworths.

DOE, 1994. Handbook of methods for the analysis of the various parameters of the carbon dioxide system in seawater, version $2 \mathrm{~A}$. In: Dickson, A.G., Goyet, C. (Eds.), ORNL/CDIAC-74.

Eigen, M., 1964. Proton transfer, acid-base catalysis, and enzymatic hydrolysis. Angew. Chem., Int. Ed. Engl. 3, 1-19.

Eigen, M., Kustin, K., Maass, G., 1961. Die Geschwindigkeit der Hydratation von $\mathrm{SO}_{2}$ in wässriger Lösung. Z. Phys. Chem. N.F. 30, 130-136.
Espie, G.S., Colman, B., 1986. Inorganic carbon uptake during photosynthesis: I. A theoretical analysis using the isotope disequilibrium technique. Plant. Physiol. 80, 863-869.

Field, C.B., Behrenfeld, M.J., Randerson, J.T., Falkowski, P., 1998. Primary production of the biosphere: integrating terrestrial and oceanic components. Science 281, 237-240.

Good, N.E., Winter, W., Conolly, T.N., Izawa, S., Singh, R., 1966. Hydrogen ion buffers for biological research. Biochemistry 5, 467-477.

Houghton, J.T., Meira Fiho, L.G., Bruce, J., Lee, H., Callander, B.A., Haites, E., Harris, N., Maskell, K. (Eds.), Climate Change 1994, Ch. Radiative Forcing of Climate Change and an Evaluation of the IPCC IS92 Emission Scenario. Cambridge Univ. Press, Cambridge.

Johnson, K.S., 1982. Carbon dioxide hydration and dehydration kinetics in seawater. Limnol. Oceanogr. 27, 849-855.

Moré, J.J., 1977. The Levenberg-Marquardt algorithm: implementation and theory. In: Watson, G.A. (Ed.), Numerical Analysis, Lecture Notes in Mathematics, vol. 630. Springer, pp. 105-116.

Rost, B., Riebesell, U., Burkhardt, S., Sültemeyer, D., 2003. Carbon acquisition of bloom-forming marine phytoplankton. Limnol. Oceanogr., 55-67.

Rost, B., Richter, K.-U., Riebesell, U., Hansen, P.J., in press. Inorganic carbon acquisition in red-tide dinoflagellates. Plant Cell Environ. doi:10.1111/j.1365-3040.2005.01450.x.

Roy, R.N., Roy, L.N., Lawson, M., Vogel, K.M., Porter-Moore, C., Pearson, T., Good, C.E., Millero, F.J., Cambel, D.J., 1993. Determination of the ionization constants of carbonic acid in seawater in salinities 5 to 45 and temperatures 0 to $45{ }^{\circ} \mathrm{C}$. Mar. Chem. 44 , 249-267.

Sabine, C.L., Feely, R.A., Gruber, N., Key, R.M., Lee, K., Bullister, J.L., Wanninkhof, R., Wong, C.S., Wallace, D.W.E., Tilbrook, B., Millero, F.J., Peng, T.-H., Kozyr, A., Ono, T., Rios, A.F., 2004. The oceanic sink for anthropogenic $\mathrm{CO}_{2}$. Science 305, 367-371.

Shampine, L.F., Reichelt, M.W., 1997. The matlab ODE suite. SIAM J. Sci. Comput. 18, 1-22.

Sültemeyer, D., Price, G.D., Yu, J.-W., Badger, M.R., 1995. Characterization of carbon dioxide and bicarbonate transport during steady-state photosynthesis in the marine cyanobacterium Synechococcus strain PCC7002. Planta 197, 597-607.

Thoms, S., Pahlow, M., Wolf-Gladrow, D., 2001. Concentrating mechanisms in chloroplasts of eukaryotic algae. J. Theor. Biol. 208, 295-313.

Zeebe, R.E., Wolf-Gladrow, D., 2001. $\mathrm{CO}_{2}$ in seawater: equilibrium, kinetics, isotopes. Vol. 65 of Elsevier Oceanography Series. Elsevier.

Zeebe, R.E., Wolf-Gladrow, D.A., Jansen, H., 1999. On the time required to establish chemical and isotopic equilibrium in the carbon dioxide system in seawater. Mar. Chem. 65, 135-153. 